\title{
Characteristics of lightning-generated electric fields measured in the Bogotá Savanna, Colombia
}

\section{Características de los campos eléctricos generados por rayos medidos en la Sabana de Bogotá, Colombia}

\author{
Herbert Rojas ${ }^{1}$, Audrey Cruz $^{2}$, Camilo Cortés ${ }^{3}$ \\ ${ }^{1}$ Electromagnetic Compatibility and Interference research group GCEM-UD, Department of Electrical Engineering, \\ Universidad Distrital Francisco José de Caldas, Bogotá, Colombia. Email: herojasc@udistrital.edu.co \\ ${ }^{2}$ Universidad Nacional de Colombia, Bogotá, Colombia. Email: auscruzbe@ unal.edu.co \\ ${ }^{3}$ Electromagnetic Compatibility research group EMC-UN, Department of Electrical and Electronic Engineering, \\ Universidad Nacional de Colombia, Bogotá, Colombia. Email : caacortesgu@unal.edu.co \\ ReCEIVED: December 20, 2016. ACCEPTED: February 27, 2017. FinAl Version: May 15, 2017.
}

\begin{abstract}
In this paper, important features of electric fields produced by cloud-to-ground (CG) lightning flashes in the central region of Colombia are analyzed. This study is the first conducted in the country where more than 100 CG lightning flash signatures are analyzed. The measurements were conducted at Bogotá, Colombia between August-September 2016. A total of 138 electric field waveforms obtained from 7 thunderstorms events with an average duration of 2.7 hours were included. The distance of the electric field signatures with respect to the measuring system was in the range between 40 and $249 \mathrm{~km}$. The statistical analysis showed that $38 \%$ of the recorded negative CG flashes were singlestrokes, which is a high percentage in comparison with other tropical and sub-tropical regions. The maximum multiplicity during the season was 9 strokes per flash and the average duration of the multiple-stroke flashes was 165 ms. In addition, although electric field signatures present a signal-to-noise ratio (SNR) with a medium level, the preliminary breakdown pulse train was identified in $22.8 \%$ of the recorded flashes. The minimum and maximum duration of preliminary breakdown for the examined negative flashes were $800 \mathrm{~ns}$ and $22 \mathrm{~ms}$, respectively.
\end{abstract}

KEYWORDS: Cloud-to-ground lightning, Electric field, Negative return stroke, Preliminary breakdown pulses.

\section{RESUMEN}

En este artículo se presentan y analizan características importantes de los campos eléctricos producidos por rayos (flashes) nube-tierra (CG) en la región central de Colombia. Este estudio es el primero llevado a cabo en el país donde se analizan más de 100 registros de rayos CG. Las mediciones se realizaron en Bogotá, Colombia entre agosto y septiembre de 2016. En total, se incluyeron 138 formas de onda de campo eléctrico obtenidas a partir de 7 tormentas eléctricas con una duración media de 2,7 horas. La distancia de los registros de campo eléctrico estuvo entre 40 y 249 $\mathrm{km}$ con respecto al sistema de medición. El análisis estadístico mostró que el $38 \%$ de los rayos CG negativos registrados presentaron una sola descarga de retorno (return stroke), lo cual es un porcentaje alto en comparación con otras regiones tropicales y subtropicales. La multiplicidad máxima registrada durante la temporada fue de 9 strokes por flash y la duración media de los flashes con múltiples strokes fue de 165 ms. Además, aunque las formas de onda del campo eléctrico presentan una relación señal-a-ruido (SNR) con un nivel medio, se identificó el tren de impulsos asociados a las descargas preliminares en el $22,8 \%$ de los flashes registrados. La duración mínima y máxima de la descarga preliminar para los flashes negativos examinados fue de $800 \mathrm{~ns}$ y $22 \mathrm{~ms}$, respectivamente.

Este artículo puede compartirse bajo la licencia CC BY-ND 4.0 y se referencia usando el siguiente formato: H. E. Rojas, A. S. Cruz, C. A. Cortés, "Characteristics of lightning-generated electric fields measured in the Bogotá Savanna, Colombia", UIS Ingenierías, vol. 16, no. 2, pp. 243 - 252, Julio - Diciembre 2017. 
PALABRAS ClAVE: Rayos nube-tierra, Campo eléctrico, Descarga de retorno negativa, Pulsos de descargas preliminares.

\section{INTRODUCTION}

Lightning flashes are transient discharges of high current that can be generated in the atmosphere by cumulonimbus clouds, volcanic eruptions, dust storms, and snowstorms [1]. These electrical discharges can be classified in four categories: intracloud, intercloud, cloud-to-air and cloud-to-ground (CG) discharges. While an average of $75 \%$ lightning discharges are related with the first three categories (cloud discharges), the remaining 25\% are CG flashes. A typical CG lightning flash is composed by more than one return stroke discharge (leader/return stroke sequence). The number of strokes in a flash is referred as the multiplicity. The return strokes (RS) have a duration of tens of microseconds, and are typically separated in time from $20 \mathrm{~ms}$ to $100 \mathrm{~ms}$ [2].

Regarding to the direction in which the charges move and their polarity, CG lightnings are divided in downward negative lightning, upward negative lightning, downward positive lightning and upward positive lightning. It is considered that downward negative lightning flashes represent more than $90 \%$ of global CG discharges and that $10 \%$ (or less) are downward positive lightnings [3]. The upward lightning discharges are related with the presence of tall structures (higher than $100 \mathrm{~m}$ ) or with objects with moderate height located on mountains tops. Due to this behavior and its high percentage of occurrence, this paper focuses on the study and characterization of downward negative CG flashes.

Several parameters of CG lightnings such as current, electric charge on clouds and charge transfer, which are used in atmospheric physics and different lightning studies, can be obtained from the signatures (measurements) of electromagnetic fields radiated by lightning flashes [3], [4]. The adequate estimation of lightning parameters and their statistical information is important for the development and implementation of lightning discharge models, to design and improve lightning protection systems for humans, equipment and installations, and to determine the electromagnetic compatibility requirements for electric and electronic devices, among others.

The electric field signature of a CG lightning flash sometimes reveals the presence of a pulse train composed by pulses with a microsecond-scale. This pulse train is known as the preliminary breakdown (PB) and its features have been analyzed in different regions of the world [5]-[10]. The PB is produced inside the cloud by a vertical discharge between the negative charge packet and the lower positive charge packet [4], [8]. For this reason, $\mathrm{PB}$ pulses can provide information about the first event that produce the electrical breakdown inside the clouds.

Comparative studies about the lightning discharge processes in different meteorological conditions can contribute to stablish the return strokes characteristics and provide a better understanding of the lightning phenomena [4], [10]-[12]. However, there are only a few measurements done in the tropical regions (Sri Lanka, Malaysia and Indonesia). For this reason, this paper presents the results of a research carried out in the Bogotá savanna (central region of Colombia) based on measurements of the electric field produced by negative CG lightning flashes. The importance of these results is that Bogotá is located in the tropical region of the planet but have cold weather and moderate humidity due to the conditions of the mountainous region where it is placed (above 2500 meters of altitude). In addition, this is the first study of its kind that it is conducted in this region of the country.

\section{DATA AND INSTRUMENTATION}

The electric field measurements were performed from August $24^{\text {th }}$ to September $14^{\text {th }}$ of 2016 during the beginning of the second rainy season in Bogotá, Colombia. Bogotá is placed at $2550 \mathrm{~m}$ above sea level in a tropical region near to the equator (between $4.478^{\circ} \mathrm{N}$ and $4.772^{\circ} \mathrm{N}$ latitudes). The region around the city has a cold weather due its location on the southwestern part of the Altiplano Cundiboyacense (montane savanna) at the Colombian central mountain range. The measuring station was situated at block B5 of the Camilo Torres Unit, which is attached to Campus of the Universidad Nacional de Colombia $\left(4.641^{\circ} \mathrm{N}, 74.091^{\circ} \mathrm{W}\right)$.

The measuring system is composed by a 1.5 meters height parallel flat-plate antenna, which had two circular plates with diameter of $0.45 \mathrm{~m}$ with a separation of 0.03 $\mathrm{m}$. The signals from the antenna were fed into a digital oscilloscope Agilent DSO6104A using an electronic circuit based on the fast buffer BUF602. The function of the buffer, besides isolating the impedance of the parallel-plate antenna, is to provide the sufficient power to the measured signal to travel through the long coaxial cable and reach the recording equipment without significant losses.

A $50 \mathrm{~cm}$ long RG-58 coaxial cable was used between the antenna and the electronic buffer circuit, and another 12 $\mathrm{m}$ long RG-58 coaxial cable was connected between the buffer and the digital oscilloscope. The oscilloscope 
operated at a sampling time of $100 \mathrm{~ns}$ with a $500 \mathrm{~ms}$ full observation window. In addition, the trigger level was set at $200 \mathrm{mV}$ and a $75 \mathrm{~ms}$ pre-trigger was adjusted in order to acquire signals before and after the trigger transient pulse. The decaying time constant of the buffer was set to approximately $38 \mathrm{~ms}$. In addition, the time stamp for the signatures (mm_dd_hh:mm:sss_yy) is obtained using the LAN connection of the oscilloscope and a personal computer (PC). In this process, the recorded signatures are downloaded from the oscilloscope to the PC, and its date information is continuously updated using an internet connection. The summarized scheme of the electric field measuring system is presented in Figure 1.

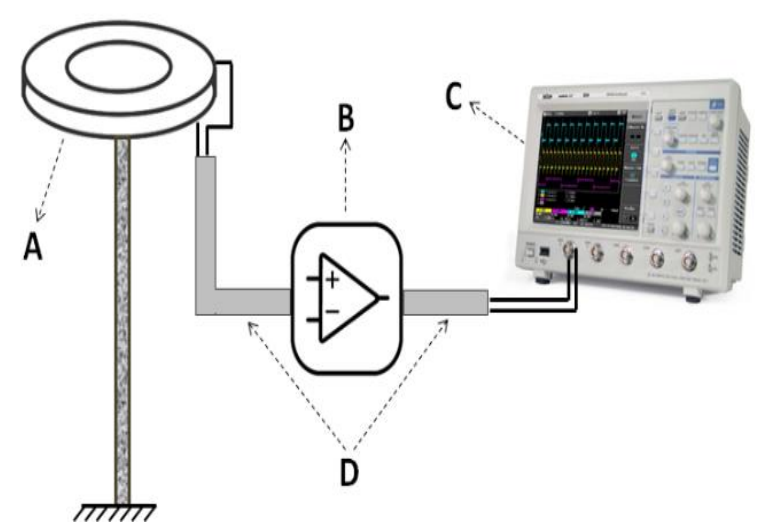

Figure 1. Electric field system; (A) parallel plate antenna; (B) electronic circuit; (C) oscilloscope; (D) coaxial cables. Source: Authors.

The electric field sensor was located on the roof of the building with an approximate height of the 15 meters from the ground level. Because of this, it was necessary to determine an additional correction factor due to the influence of the buildings and other structures near to the antenna. The complete calibration process of the measuring system can be reviewed in [13]. During the installation of the measuring system, the characteristics of the electromagnetic environment were analyzed using the data collected in [14]. In addition, it was ensured that the grounding system complied with the requirements established for this type of measurements by applying the methodology presented in [15].

\section{RESULTS AND DISCUSSION}

In order to avoid the horizontal component of the electric field, the antenna was oriented perpendicular to the vertical electric field vector or parallel to the ground plane. Using the measuring system described above, electric field signatures (slow and fast fields) were recorded from seven (7) thunderstorms obtaining $138 \mathrm{CG}$ lightning flashes. From these records, the analysis was divided in two sections: lightning flash and the preliminary breakdown characteristics.

\subsection{Lightning flash characterization}

The distance of the lightning flashes was estimated with data provided by the Colombian Lightning Location Network (CLLN) operated by the company Keraunos, which is a subsidiary of the LINET network [16], [17]. It is worth clarifying that it was not possible to correlate the parameters of CG lighting flashes obtained in this study with the parameters of the flashes measured by CLLN, due to the available information that was provided.

Table 1 shows the global information of the thunderstorms analyzed in this work. From $138 \mathrm{CG}$ lightning signatures, $76 \%$ of the $\mathrm{CG}$ flashes occurred at distance larger than $50 \mathrm{~km}$ from the measuring station. It was also observed that $127(92 \%)$ flashes had negative polarity, while the remaining $11(8 \%)$ were positive flashes. These percentages are similar to those reported by several researchers [3], [18], [19]. In addition, the average number of strokes per flash was 2.4 and the maximum multiplicity was nine (9) strokes. The flash with the maximum multiplicity was recorded on September $8^{\text {th }}$ at 19:33:59 as illustrated in Figure 2.

Table 2. Summarized information of the thunderstorms

\begin{tabular}{|ccccc|}
\hline $\begin{array}{c}\text { Storm } \\
\text { Date }\end{array}$ & $\begin{array}{c}\text { Total } \\
\text { Flahes }\end{array}$ & $\begin{array}{c}\text { \% single } \\
\text { stroke } \\
\text { flashes }\end{array}$ & $\begin{array}{c}\text { Maximum } \\
\text { multiplicity }\end{array}$ & $\begin{array}{c}\text { Average } \\
\text { multip }\end{array}$ \\
\hline $24 / 8 / 2016$ & 21 & 38.1 & 7 & 2.6 \\
$29 / 8 / 2016$ & 13 & 46.2 & 6 & 2.5 \\
$30 / 8 / 2016$ & 6 & 33.3 & 3 & 1.8 \\
$3 / 9 / 2016$ & 15 & 66.7 & 5 & 1.6 \\
$8 / 9 / 2016$ & 12 & 58.3 & 9 & 2.4 \\
$13 / 9 / 2016$ & 39 & 35.9 & 6 & 2.5 \\
$14 / 9 / 2016$ & 32 & 31.3 & 8 & 3.2 \\
\hline
\end{tabular}

Source: Authors. 


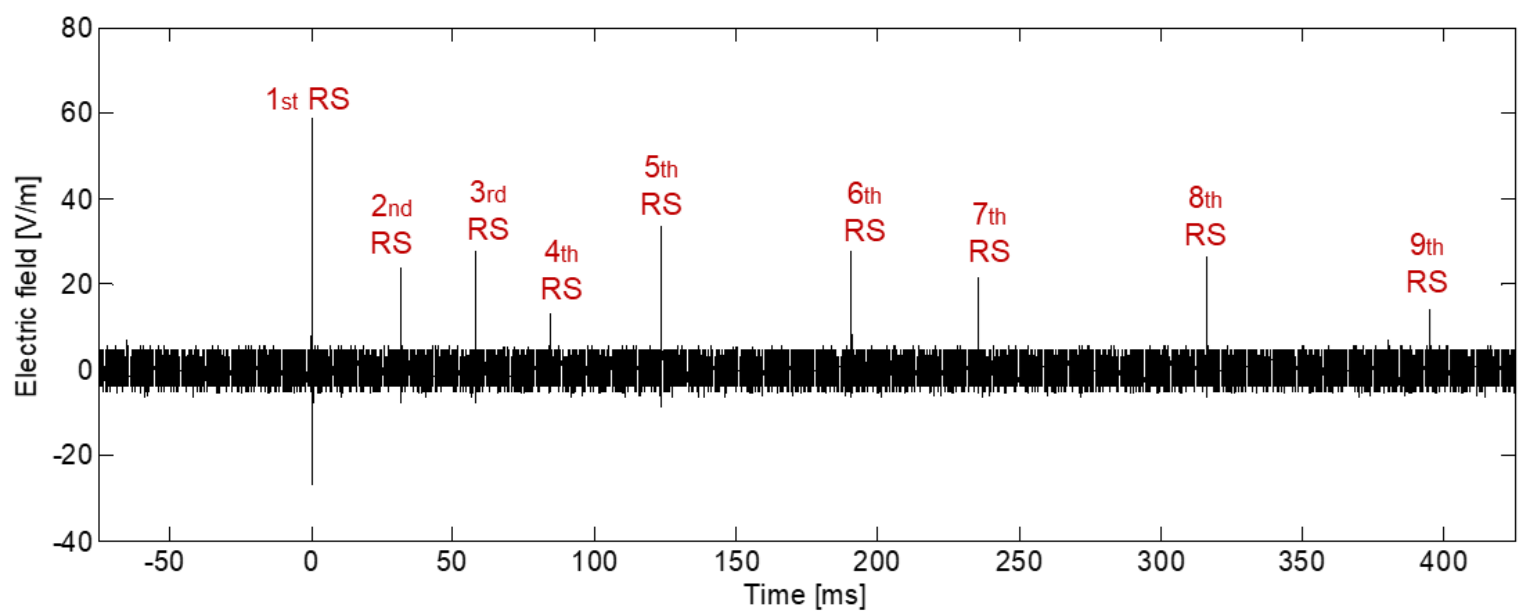

Figure 2. Electric field signature of negative CG lightning flash with the maximum number of return strokes recorded during the season of measurements. Signature recorded on 08/09/16 at 19:33:59 hours. Approximate distance of 123.5 km. Source: Authors.

With respect to negative CG lightnings, the percentage of the single-stroke flashes (SSF) was about $38 \%$, which is a high value in comparison with other tropical and subtropical regions such as Sri Lanka (21\%) [20], Florida (17\%) [21], Malaysia (16\%) [22] and Brazil (17\%) [23]. This value can be related with the altitude of Bogotá (mountainous region) taking into account that a previous study performed in Zhongchuan, China (1900 meters above sea level) reported a percentage of $39.8 \%$ in the SSF [5], very similar to the value obtained in Bogotá .

One of the most important parameters of negative CG lightnings is the interstroke interval of multiple stroke flashes [10]. Figure 3 shows the interstroke interval of multiple strokes flashes. In this study, 211 subsequent return strokes (SRS) from 79 negative CG flashes were analyzed. The obtained results show that the minimum, maximum, arithmetic mean (AM), geometric mean (GM) of the interstroke intervals were $2.8 \mathrm{~ms}, 307.5 \mathrm{~ms}, 61.9$ $\mathrm{ms}$, and $47.7 \mathrm{~ms}$, respectively.

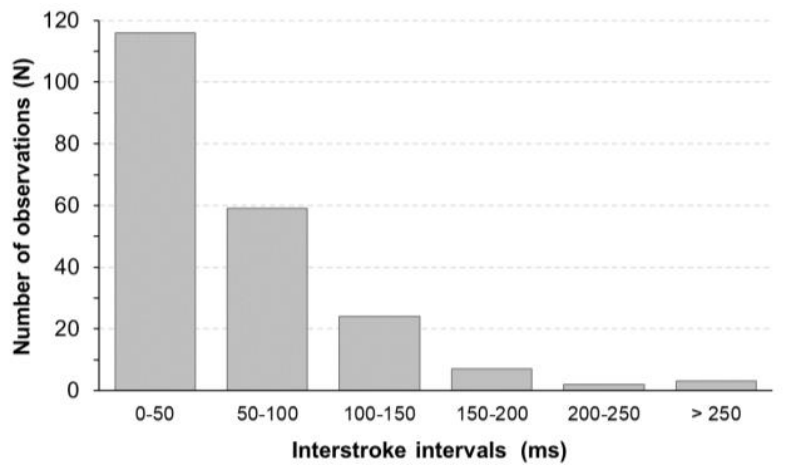

Figure 3. Histogram of the interstroke intervals for negative CG lightning flashes (Total observations: 211 intervals). Source: Authors.
On the other hand, the flash duration was also analyzed. The distribution of this temporal parameter is shown in Figure 4. For the 79 negative CG flashes, the minimum and maximum duration were $8.8 \mathrm{~ms}$ and $415.2 \mathrm{~ms}$, respectively. In addition, the AM was $165.1 \mathrm{~ms}$, while the GM was $114.7 \mathrm{~ms}$. It is important to note that multiplicity and flash duration may depend on the observation window used during the measurements. In this case, all lightning flash parameters discussed in this section were obtained using a $425 \mathrm{~ms}$ period (after the first RS).

\subsection{Preliminary breakdown characteristics}

In order to analyze the parameters of the PB trains, some definitions about the pulse train, individual pulse duration and interpulse duration have been adopted from the previous works developed by Nag \& Rakov [24], [25]. These definitions are follows:

- Pulse train duration: time interval between the peaks of the first and last pulses in the train.

- Individual pulse duration: the full width of the pulse

- Interpulse duration: the time interval between the peaks of two consecutive pulses.

From descriptions presented above, PB pulse trains can be grouped using two definitions (models), the BIL model and BL model. The "B,I,L" (B: breakdown, I: intermediate, L: leader) description was defined by Clarence \& Malan (1957) and it is used to identify the pattern of electric field changes (pulse train and the interimpulse durations) preceding the first negative $\mathrm{CG}$ flashes [26]. The BIL model is composed by the following stages [4], [8]: 


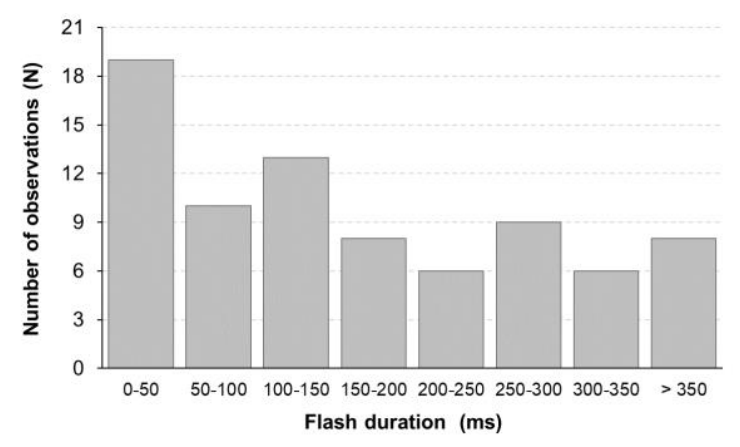

Figure 4. Histogram of the flash duration for negative $\mathrm{CG}$ lightnings (Total observations: 79 multiple stroke flashes). Source: Authors.

- Initial breakdown (B): lasting some milliseconds, this stage radiates intense electromagnetic fields and it is followed by an intermediate stage with little radiation.

- Intermediate stage (I): lasting up to several hundred milliseconds, ending with the onset of stepped leaders.

- Stepped leaders (L): lasting a few milliseconds at the most, this section produces intensive electromagnetic radiations. This stage finally ends with the RS.
Figure 5 and Figure 6 show an example of the typical electric field changes due to the generation of a negative CG lightning flash, which is initiated by PB pulses with a BIL form (see Figure 6a). For this signature, two PB trains were observed and seven RS were recorded inside the observation window $(500 \mathrm{~ms})$. In this case, the magnitude of the PB pulse trains are slightly less than the amplitude of the FRS (see Figure 6b). In addition, the PB pulses and the FRS have the same polarity. However, this condition is not the same for all the recorded signatures due to random behavior of the lightning flashes.

On the other hand, the BL model is related with PB pulses that might have a duration zero in the intermediate stage (I). An example of the BL model form is shown in Figure 7 and Figure 8. In this case, it is not clear the presence of an intermediate stage without electromagnetic radiations. A close up of the region that covers the PB pulse train and the FRS is presented in Figure $8 \mathrm{a}$ and Figure $8 \mathrm{~b}$. Besides, it is possible to observe that the pulses contained in the train present a random behavior and they have irregular and complex waveforms. These characteristics are common in the pulses of the PB stage.

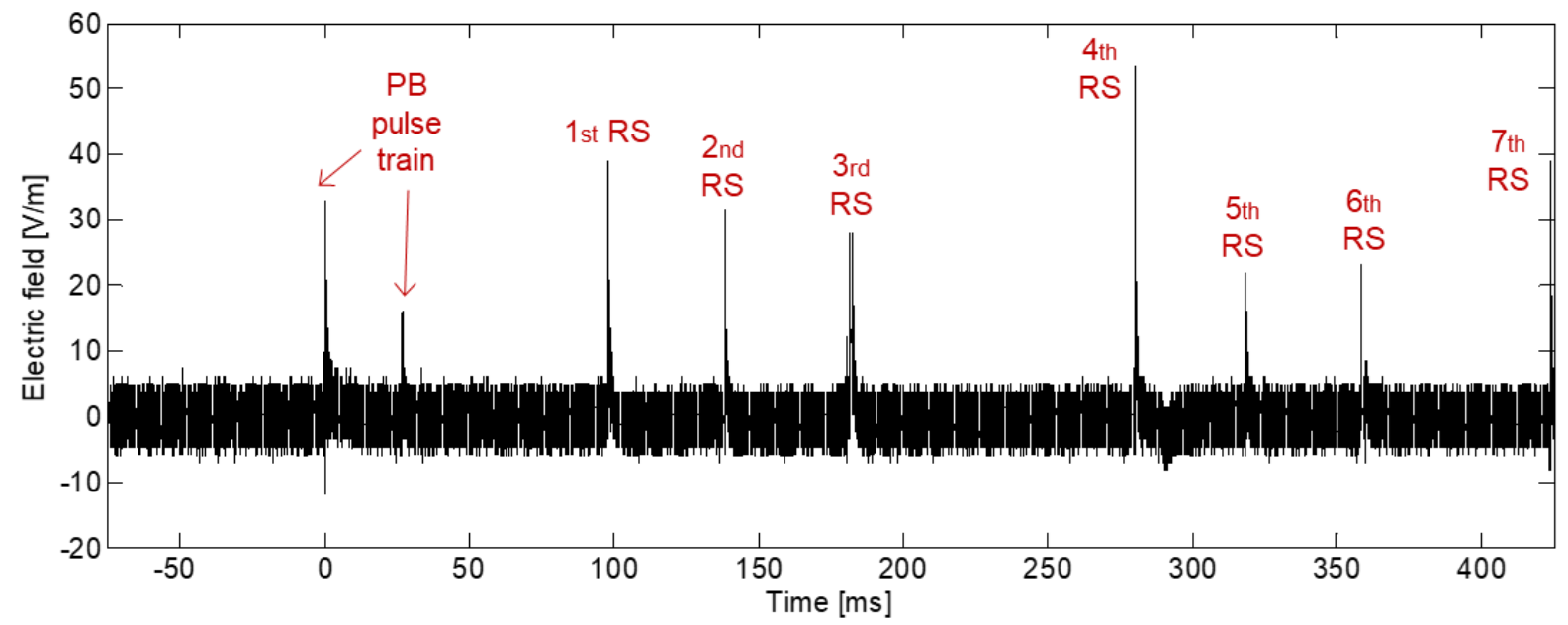

Figure 5. Electric field signature of negative CG lightning flash showing a pronounced preliminary breakdown (PB) pulse train. Signature recorded on 14/09/16 at 19:22:10 hours. Approximate distance of 21.8 km. Source: Authors. 


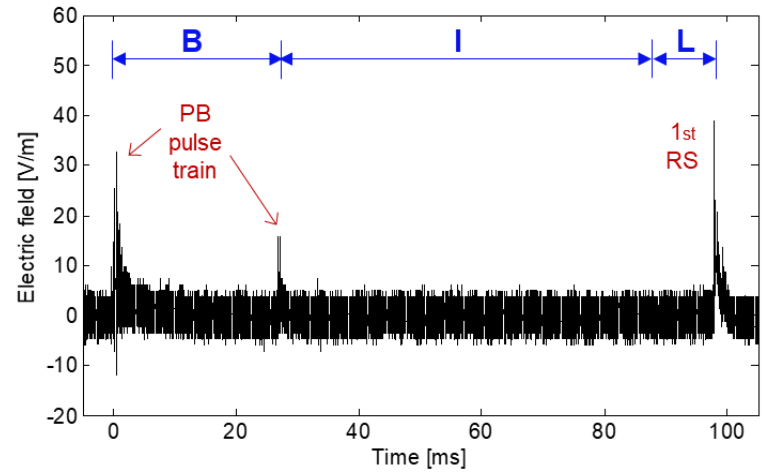

(a)

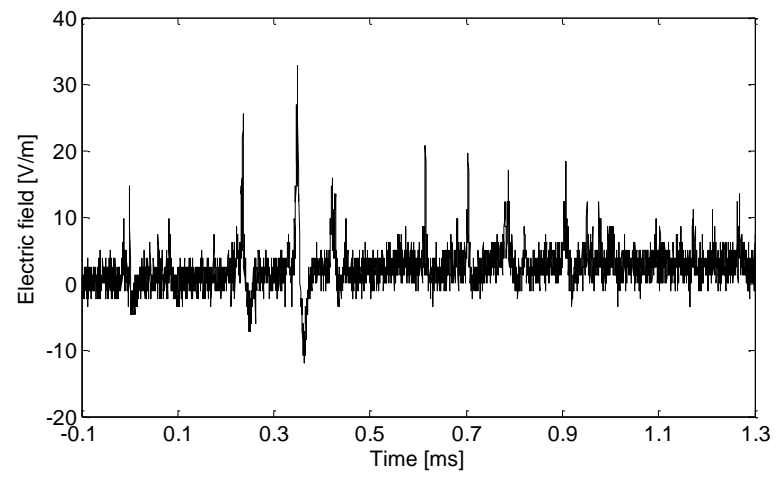

(b)

Figure 6. Zoom of the electric field signature shown in Figure 5. (a) PB pulse train and the FRS; (b) PB structure with irregular pulses and complex waveform. Source: Authors

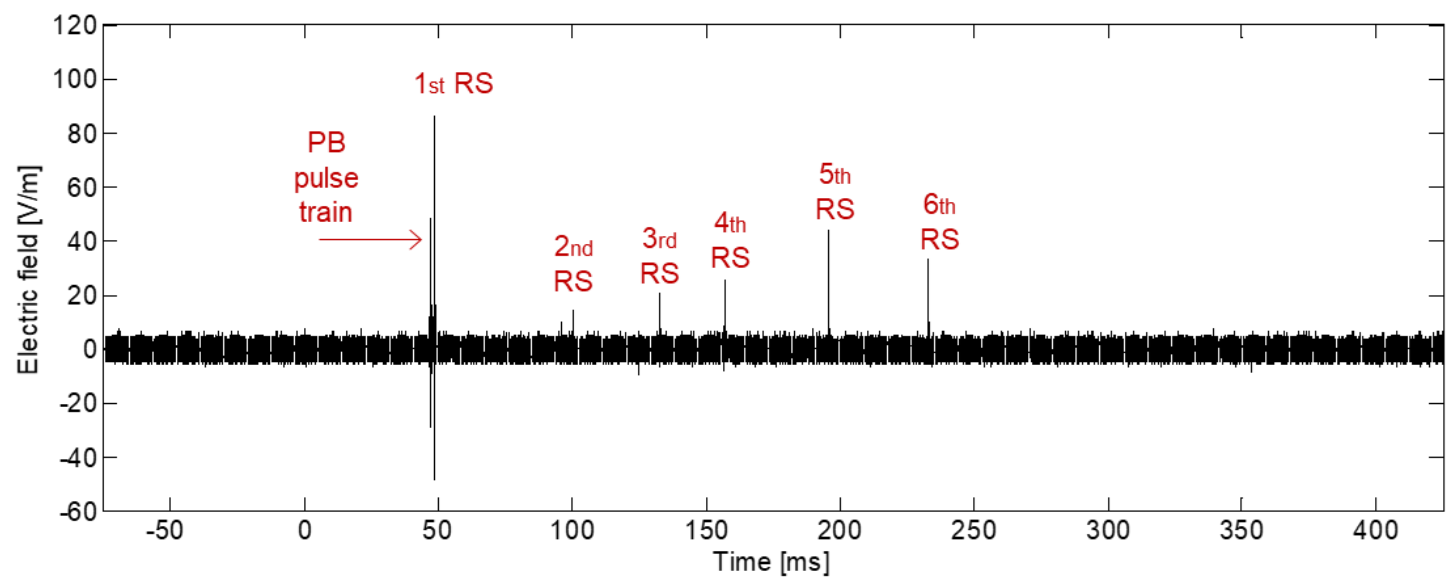

Figure 7. Electric field signature of negative CG lightning flash showing an evident preliminary breakdown (PB) pulse train. Signature recorded on 14/09/16 at 18:35:35 hours. Approximate distance of $56.7 \mathrm{~km}$. Source: Authors.

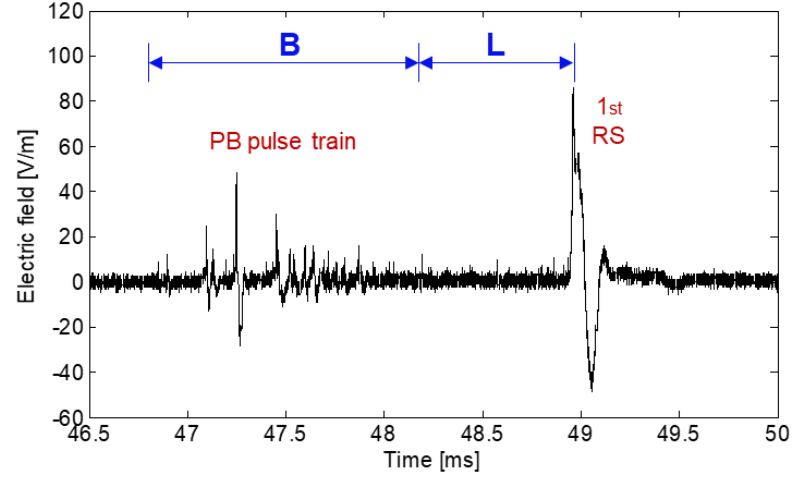

(a)

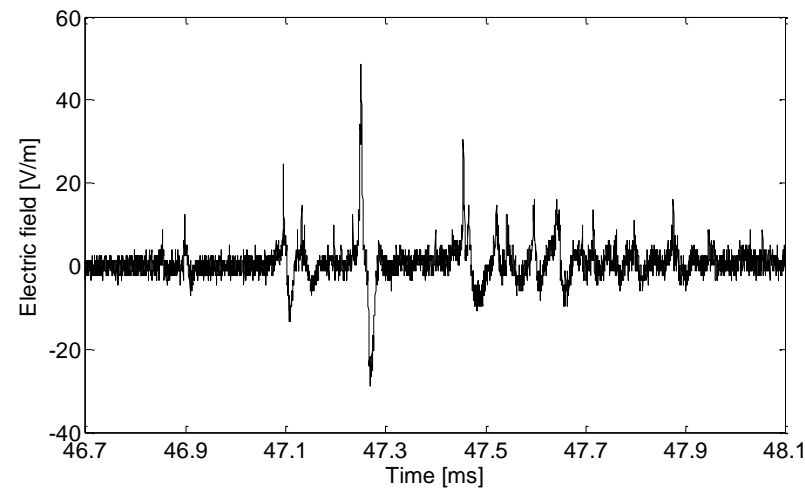

(b)

Figure 8. Zoom of the electric field signature shown in Figure 7. (a) PB pulse train and the FRS; (b) PB pulse train with irregular pulses and complex waveform. Source: Authors.

The recorded electric field data have been examined and it was found that 29 (22.8\%) waveforms of 127 negative CG lightning flashes exhibited PB pulse trains. In this case, the low percentage of the identified PB pulses was affected by the level of the noise components present in the measurements (between $3 \mathrm{~V} / \mathrm{m}$ and $5 \mathrm{~V} / \mathrm{m}$ ) and the observation distance. This scenario is according with observations reported by Baharudin et al. [8] and Zhu et al. [27]. From 29 negative CG flashes that showed PB stage, $65.5 \%$ (19 signatures) agree with the BIL model, while $24.1 \%$ (7 signatures) fit with the BL description. For the remaining $10.4 \%$ (3 signatures) the PB stage 
presented an irregular pattern and they cannot categorized into either BIL or BL description.

Figure 9 shows the distribution of the duration time for the 29 PB pulse trains that were analyzed. From results, it was possible to observe that the duration of the $\mathrm{PB}$ pulse trains changes from $800 \mathrm{~ns}$ to $22 \mathrm{~ms}$. However, the most of the signatures revealed a PB duration between few miliseconds and $10 \mathrm{~ms}$. Finally, the histogram for the duration of the intermediate zone is presented in Figure 10. This distribution reveals that most part of 19 records that agree with the BIL model present an intermediate zone with duration from few miliseconds up to $60 \mathrm{~ms}$. In this case, the maximum duration was $133.2 \mathrm{~ms}$.

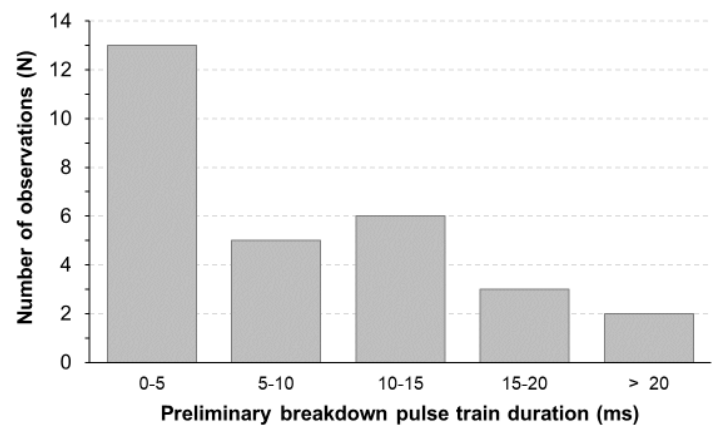

Figure 9. Distribution of the PB pulse train duration. Source: Authors.

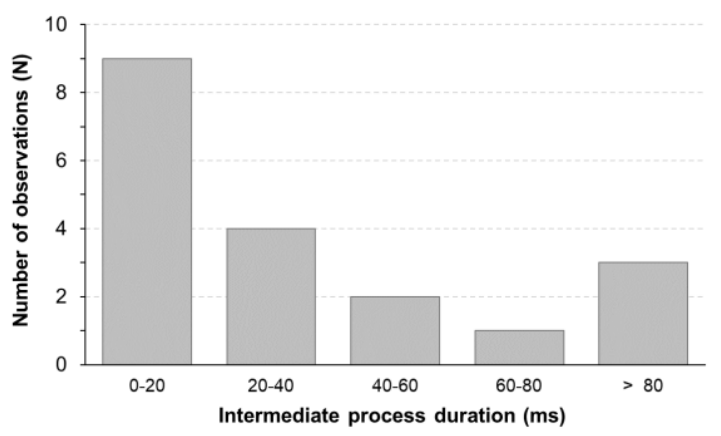

Figure 10. Distribution of the intermediate time duration. Source: Authors.

\section{CONCLUSIONS}

In this paper, the characterization and analysis of negative CG lightning flash parameters recorded in Bogotá, Colombia was presented. This study was focused on the analysis of polarity, multiplicity and duration of the lighting flashes and the main features of the preliminary breakdown pulse trains.

The results showed that 127 of 138 CG lightning flashes recorded in Colombia between August and September 2016 exhibited negative polarity (92\%). The average number of strokes per flash was 2.4 and the maximum multiplicity recorded in an observation window of 500 ms (75 ms pre-trigger) was 9 strokes. Taking into account this temporal window, some parameters such as the average multiplicity, the maximum multiplicity, and other temporal parameters may be limited by the recorded data.

On the other hand, the percentage of single single-stroke flashes (SSF) was about 38\%, which is a high value in comparison with other tropical and sub-tropical regions such as Sri Lanka, Malaysia, Florida and Brazil. This value could be related with the altitude of Bogota savanna (average of 2550 masl). However, it is necessary develop new measurement seasons in order to validate this hypothesis.

Finally, a statistical analysis on 29 negative CG lightning waveforms showed that $65.5 \%$ of these signatures agreed with the BIL description (model) of lightning preliminary discharges. From these 29 signatures, 18 signals (62\%) presented a PB train duration between 0.8 and $10 \mathrm{~ms}$.

\section{ACKNOWLEDGMENT}

Prof. H. E. Rojas express his gratitude to Universidad Distrital Francisco José de Caldas for its support through the doctoral commission with contract code $\mathrm{N}^{\circ} 0002$ 2016. In addition, the authors would like to thank Daniel Aranguren Ph.D., scientific director of Keraunos, for his collaboration and facilitate the information of the Colombian lightning location network.

\section{REFERENCES}

[1] C.-L. Wooi, Z. Abdul-Malek, N.-A. Ahmad, y A. I. El Gayar, "Statistical analysis of electric field parameters for negative lightning in Malaysia", J. Atmos. SolarTerrestrial Phys., vol. 146, pp. 69-80, 2016.

[2] K. L. Cummins y M. J. Murphy, "An overview of lightning locating systems: History, techniques, and data uses, with an in-depth look at the U.S. NLDN", IEEE Trans. Electromagn. Compat., vol. 51, no 3, pp. 499-518, 2009.

[3] V. A. Rakov, "Lightning phenomenology and parameters important for lightning protection", en IX International Symposium on Lightning Protection SIPDA, 2007, no November, pp. 1-24.

[4] B. Salimi, K. Mehranzamir, y Z. Abdul-Malek, "Statistical Analysis of Lightning Electric Field Measured Under Equatorial Region Condition", Procedia Technol., vol. 11, no Iceei, pp. 525-531, 2013. 
[5] X. Qie, Y. Yu, D. Wang, H. Wang, y R. Chu, "Characteristics of Cloud-to-Ground Lightning in Chinese Inland Plateau.", J. Meteorol. Soc. Japan, vol. 80, no 4, pp. 745-754, 2002.

[6] W.-S. Dong, X.-S. Liu, Y.-J. Zhang, C.-X. Chen, y J.-G. Wang, "Lightning electromagnetic radiation field spectra in the interval from 25 to $100 \mathrm{MHz}$ ", Zhongguo Dianji Gongcheng Xuebao/Proceedings Chinese Soc. Electr. Eng., vol. 23, no 3, pp. 104-107, 2003.

[7] Z. A. Baharudin, M. Fernando, N. A. Ahmad, J. S. Mäkelä, M. Rahman, y V. Cooray, "Electric field changes generated by the preliminary breakdown for the negative cloud-to-ground lightning flashes in Malaysia and Sweden", J. Atmos. Solar-Terrestrial Phys., vol. 8485 , pp. 15-24, ago. 2012.

[8] Z. A. Baharudin, N. A. Ahmad, M. Fernando, V. Cooray, y J. S. Mäkelä, "Comparative study on preliminary breakdown pulse trains observed in Johor, Malaysia and Florida, USA", Atmos. Res., vol. 117, pp. 111-121, 2012.

[9] S. N. M. Arshad, M. Izadi, M. Z. A. Ab Kadir, M. A. Abd Bari, N. Rameli, N. Abdul Rahim, y M. N. Hamzah, "Characterization preliminary breakdown in the measured lightning electric fields", 8th Int. Power Eng. Optim. Conf. PEOCO 2014, no March, pp. 435438, 2014.

[10] A. Hazmi, P. Emeraldi, M. I. Hamid, y N. Takagi, "Some characteristics of multiple stroke negative cloud to ground lightning flashes in Padang”, Int. J. Electr. Eng. Informatics, vol. 8, no 2, pp. 438-450, 2016.

[11] M. A. Haddad, V. A. Rakov, y S. A. Cummer, "New measurements of lightning electric fields in Florida: Waveform characteristics, interaction with the ionosphere, and peak current estimates", J. Geophys. Res. Atmos., vol. 117, no 10, 2012.

[12] S. N. M. Arshad, M. Z. A. Ab Kadir, M. Izadi, M. N. Hamzah, C. Gomes, y J. Jasni, "Characterization of measured lightning electric fields observed in Malaysia", Int. Conf. Light. Prot. (ICLP 2014), pp. 1058-1063, 2014.

[13] H. E. Rojas, C. A. Rivera, J. Chaves, C. A. Cortés, F. J. Roman, y M. Fernando, "New Circuit for the Measurement of Lightning Generated Electric Fields", en 2017 International Symposium on Lightning Protection (XIV SIPDA), 2017, pp. 1-7.
[14] C. C. Rodríguez, S. M. Peña, y H. O. Boada, "Estudio de los niveles de radiación electromagnética no ionizante en varias zonas de la ciudad de Bucaramanga", Rev. UIS Ing., vol. 9, no 2, pp. 207-218, 2010.

[15] Y. P. Goyes Peñafiel, G. Jimenez Diaz, y R. Mier Umaña, "Aplicación del método de inversión usando mínimos cuadrados (DLS) para el procesamiento de sondeos eléctricos verticales en Campo Escuela Colorado (Santander) - Caso de estudio", Rev. UIS Ing., vol. 15, no 2, pp. 125-133, ene. 2016.

[16] C. Tovar, D. Aranguren, J. Lopez, J. Inampues, y H. Torres, "Lightning risk assessment and thunderstorm warning systems", en International Conference on Lightning Protection (ICLP 2014), 2014, pp. 1870-1874.

[17] D. Aranguren, C. Tovar, J. Inampués, J. Lopez, E. Soto, y H. Torres, "Lightning effects on distribution transformers and reliability of power distribution systems in Colombia", Ing. e Investig., vol. 35, no Sup 1, pp. 2833, 2015.

[18] U. Sonnadara, V. Cooray, y T. Götschl, "Characteristics of cloud-to-ground lightning flashes over Sweden”, Phys. Scr., vol. 74, no 5, pp. 541-548, 2006.

[19] M. A. Uman, The Lightning Discharge. New York, USA: Courier Dover Publications, 2012.

[20] V. Cooray y K. P. S. C. Jayaratne, "Characteristics of lightning flashes observed in Sri Lanka in the tropics", J. Geophys. Res., vol. 99, no D10, p. 21051, 1994.

[21] V. A. Rakov, M. A. Uman, y R. Thottappillil, "Review of lightning properties from electric field and TV observations", J. Geophys. Res., vol. 99, no D5, p. 10745, 1994.

[22] Z. A. Baharudin, N. A. Ahmad, J. S. Mäkelä, M. Fernando, y V. Cooray, "Negative cloud-to-ground lightning flashes in Malaysia", J. Atmos. SolarTerrestrial Phys., vol. 108, pp. 61-67, 2014.

[23] M. G. Ballarotti, C. Medeiros, M. M. F. Saba, W. Schulz, y O. Pinto, "Frequency distributions of some parameters of negative downward lightning flashes based on accurate-stroke-count studies", J. Geophys. Res. Atmos., vol. 117, no D6, p. n/a-n/a, mar. 2012.

[24] A. Nag y V. A. Rakov, "Pulse trains that are characteristic of preliminary breakdown in cloud-toground lightning but are not followed by return stroke pulses", J. Geophys. Res. Atmos., vol. 113, no 1, pp. 112, 2008. 
[25] A. Nag y V. A. Rakov, "Electric Field Pulse Trains Occurring Prior to the First Stroke in Negative Cloud-toGround Lightning”, IEEE Trans. Electromagn. Compat., vol. 51, no 1, pp. 147-150, feb. 2009.

[26] N. D. Clarence y D. J. Malan, "Preliminary discharge processes in lightning flashes to ground", Q. J. R. Meteorol. Soc., vol. 83, no 356, pp. 161-172, abr. 1957.

[27] Y. Zhu, V. A. Rakov, S. Mallick, y M. D. Tran, "Characterization of negative cloud-to-ground lightning in Florida", J. Atmos. Solar-Terrestrial Phys., vol. 136, pp. $8-15,2015$ 